Vol. 1 No. 2 September 2021, e-ISSN : 2797-8842 | p-ISSN : 2797-9431

\title{
PENERAPAN MODEL TEAMS GAMES TOURNAMENT (TGT) TERHADAP AKTIVITAS DAN HASIL BELAJAR SISWA KELAS X IIS 3 SMA NEGERI 1 TELAGASARI PADA MATA PELAJARAN GEOGRAFI
}

\author{
IDA NURAIDA \\ SMA Negeri 1 Telagasari \\ e-mail : nuraidai614@gmail.com
}

\begin{abstract}
ABSTRAK
Penerapan model pembelajaran kooperatif tipe Teams Games Tournament bertujuan untuk meningkatkan aktivitas dan hasil siswa kelas X IIS 3 SMA Negeri 1 Telagasari. Penelitian ini adalah penelitian tindakan kelas dilaksanakan sebanyak dua siklus. subjek dari penelitian ini adalah siswa kelas X IIS 3 SMA Negeri 1 Telagasari dengan jumlah 41 orang siswa. Data tentang aktivitas dan hasil belajar siswa dikumpulkan dengan menggunakan metode observasi dan metode test.semua data dianalisis menggunakan teknik deskriptif kualitatif. Hasil penelitian pada aktivitas belajar siswa menunjukkan peningkatan dari siklus I 70,10\% yang berada pada kriteria cukup aktif menjadi $81,67 \%$ pada siklus II yang berada pada kriteria aktif. Sedangkan pada hasil belajar pada siklus I $73,04 \%$ yang berada pada kriteria sedang menjadi $80,00 \%$ pada siklus II berada pada kriteria tinggi dan ketuntasan klasikal 78,04\% .dari analisis data penelitian dapat disimpulkan bahwa, penerapan model pembelajaran kooperatif tipe Team Game Tournament dapat meningkatkan aktivitas dan hasil belajar geografi siswa kelas X IIS 3 SMA Negeri 1 Telagasari
\end{abstract}

Kata Kunci : Teams Games Tournament, Aktivitas, Hasil Belajar geografi

\section{ABSTRACT}

The implementation of cooperative learning model type Teams Games Tournament grade $\mathrm{X}$ IIS 3 SMA Negeri 1 Telagasari. The research aims to improve the learning result of activity through. The research is research conducted a class act as much as two cycles. the subject of this research is the students of class X IIS 3 SMA Negeri 1 Telagasari with number of 41 students. Data about student learning activities and outcomes are collected using the methods of observation and test methods. all data were analyzed using descriptive qualitative techniques. The research on student learning activities shows an improvement of the cycle $170,10 \%$ which is quite active on the criteria being $81,67 \%$ in cycle II, who is on the active criteria. Whereas the results of the study on cycle $\mathbf{1 7 3 , 0 4 \%}$ that is on the criteria $80.00 \%$ currently in cycle II is on high and with criteria of classical78,04\%. from the analysis of the research data it can be concluded that the application of the cooperative learning model, this type of Teams Games Tournament can boost the activity and results of learning geography grade X IIS 3 SMA Negeri 1 Telagasari

Key words: Cooperative Learning Model the type of gaming Tournament, Activities, Results and Learning geography.

\section{PENDAHULUAN}

Pembelajaran geografi merupakan salah satu pembelajaran yang sangat penting untuk dipelajari, pembelajaran geografi meliputi proses pembelajaran yang terintegrasi antara pengetahuan, keterampilan dan sikap, yang di dalamnya mengkaji fenomena-fenomena alam yang terjadi di muka bumi ini. Melihat kajian dari ilmu geografi tersebut maka manusia mempunyai peranan yang sangat penting untuk menentukan keadaan bumi di masa datang . Menurut Sumaatmaja (2006 ) menyatakan bahwa: " pembelajaran geografi menekankan pada aspek-aspek: (1) Alam lingkungan yang menjadi sumber daya bagi manusia, (2) Penyeberan 
umat manusia dengan variasi kehidupan, (3) Interaksi keruangan umat manusia dengan alam lingkungan yang memberikan variasi terhadap ciri ciri khas tempat- tempat di permukaan bumi, (4) Kesatuan regional merupakan matra darat, perairan, dan udara di atasnya”

Berdasarkan hal tersebut, maka siswa dituntut untuk berperan aktif dalam berkreasi dan berinovasi untuk menggali pengetahuan dan keterampilannya melalui pengamatan atau penyelidikan maupun pemberian pengalaman pembelajaran, baik secara langsung atau tidak langsung bagi siswa.dan menumbuhkan karakter yag baik.

Melihat data rendahnya tingkat aktivitas dan hasil belajar siswa khususnya dala pembelajaran Geografi, maka guru perlu memperbaiki proses pembelajaran di sekolah dengan menggunakan model pembelajaran yang sesuai dengan karakteristik siswa dan mata pelajaran geografi. Proses pembelajaran sebaiknya lebih melibatkan siswa, sehingga siswa akan cenderung aktif dalam mengikuti pembelajaran.

Namun kenyataannya, berdasarkan hasil observasi yang dilakukan di SMA Negeri 1 Telagasari ditemukan bahwa aktivitas dan hasil belajar siswa terutama dalam pelajaran Geografi masih relatif rendah. Dari hasil perolehan data nilai, pada mata pelajaran geografi kelas X IIS 3 SMA Negeri 1 Telagasari menyatakan bahwa hasil belajar Geografi siswa kelas X IIS 3 masih di bawah kriteria ketuntasan minimal (KKM) yang ditentukan oleh sekolah yaitu 78,00 hanya 24 orang yang tuntas dari 41 siswa. Hal tersebut bisa dilihat dari rata-rata hasil belajar Geografi siswa yang masih rendah. Beberapa faktor yang menyebabkan hal tersebut adalah siswa kurang fokus dan kurang berkonsentrasi pada saat proses pembelajaran berlangsung, model pembelajaran yang digunakan oleh guru juga masih menggunakan metode ceramah, dan terbatasnya media pembelajaran

Untuk meningkat aktivitas dan hasil belajar, salah satu cara dengan menggunakan model pembelajatran kooperatif tipe Teams Groups Tournament yang dikembangkan oleh Robert Slavin (1990) merupakan teknik pembelajaran dengan menggabungkan kelompok belajar dengan kompetisi tim dan bisa digunakan untuk meningkatkan pembelajaran.

Menurut Kiranawati (2007) pembelajaran kooperatif model TGT (Teams Games Tournament) adalah salah satu tipe atau model pembelajaran kooperatif yang mudah diterapkan, melibatkan aktivitas seluruh siswa tanpa harus ada perbedaan status, melibatkan peran siswa sebagai tutor sebaya dan mengandung unsur permainan dan reinforcement. Aktivitas belajar dengan permainan yang dirancang dalam pembelajaran kooperatif model TGT memungkinkan siswa dapat belajar lebih rileks disamping menumbuhkan tanggung jawab, kerjasama, persaingan sehat dan keterlibatan belajar. Selanjutnya Tampubolon (2013) menjelaskan model pembelajaran kooperatif tipe Teams Games Tournament dengan pola permainan game membagi siswa menjadi 4-5 orang. setiap kelompok mendalami meteri secara bersama yang dipersiapkan dalam game. Game terdiri atas pertanyaan-pertanyaan yang dirancang dan diberi nomor untuk menguji pengetahuan yang didapat siswa dari penyajian materi dikelas dan hasil kerja kelompok. Peserta didik memilih kartu bernomor dan mencoba menjawab pertanyaan yang sesuai dengan nomor itu. Jawaban yang benar akan mendapatkan skor. Skor peserta didik dikumpulkan untuk turnamen mingguan. Turnamen peserta, guru membagi perserta didik dalam meja turnamen. Tiap peserta didik berpresatsi tinggi dikelompokkan pada meja I, tiga peeserta didik selanjutnya pada meja II, dan sterusnya. Guru menguumkan kelompok yang menang dan masing-masing tim akan mendapatkan sertifikat atau hadiah. .

Menurut Jihan \& Haris, (2008) menyatakan hasil belajar merupakan perubahan tingkah laku siswa secara nyata setelah dilakukan proses belajar mengajar yang sesuai dengan tujuan pengajaran. Setelah melalui proses belajar maka siswa diharapkan dapat mencapai tujuan belajar yang disebut juga sebagai hasil belajar yaitu kemampuan yang dimiliki siswa setelah menjalani proses belajar.

Informasi hasil belajar siswa sangat diperlukan untuk memotivasi siswa dan untuk perbaikan serta peningkatan kualitas pembelajaran. Menurut Sudjana, (2004) menyatakan bahwa hasil belajar yang rendah merupakan cerminan dari hambatan yang muncul dalam 
kegiatan proses pembelajaran, hambatan dalam kegiatan proses pembelajaran dapat terjadi pada berbagai aspek Salah satu model pembelajaran yang mampu membantu meningkatkan aktivitas dan hasil belajar siswa dan sekaligus membantu siswa mengatasi kesulitan dalam memahami konsep, mampu mengajak siswa berperan aktif dan mampu mengarahkan siswa untuk bekerja sama dalam kelompok adalah model pembelajaran kooperatif. Dalam pembelajaran kooperatif ini guru lebih berperan sebagai fasilitator yang berfungsi sebagai jembatan penghubung ke arah pemahaman yang lebih tinggi.

Menurut Sukidin (2002) pembelajaran kooperatif adalah "pembelajaran yang memandang keberhasilan individu diorientasikan dalam keberhasilan kelompok. Dalam hal ini maka siswa berusaha keras membantu dan mendorong pada teman-teman untuk bersama-sama berhasil dalam belajar". Salah satunya adalah model pembelajaran kooperatif tipe Team Game Tournament . Tampubolon (2013) menyatakan bahwa model pembelajaran kooperatif Team Game Tournament dengan pola permainan game. Model pembelajaran kooperatif dengan melibatkan seluruh aktivitas seluruh siswa dalam permainan game dalam kelompok. Siswa belajar di kelas dengan kebersamaan, team dan mendapatkan reinforcement berupa hadiah atau sertifikat.

Menurut Komalasari, (2010) menyatakan aktivitas belajar dengan permainan yang dirancang dengan pembelajaran kooperatif Teams Games Tournament memungkinkan siswa dapat belajar lebih santai di samping menumbuhkan tanggung jawab, kerja sama, persaingan sehat, dan keterlibatan belajar Penggunaan model pembelajaran kooperatif tipe Teams Games Tournament memberikan siswa kebebasan untuk berinteraksi dan menggunakan pendapatnya, rasa percaya diri siswa menjadi semakin tinggi, motivasi belajar siswa semakin bertambah, meningkatnya toleransi antara siswa dengan siswa, guru dengan siswa. Menurut Taniredja, (2011) menyatakan bahwa "penggunaan model pembelajaran kooperatif tipe Teams Games Tournament juga memberikan kebebasan untuk mengaktualisasikan diri dengan seluruh potensi yang ada dalam diri siswa tersebut, kerja sama antar siswa juga siswa dengan guru akan membuat interaksi dalam kelas menjadikan suasana di dalam kelas menjadi hidup dan tidak membosankan”. Selanjutnya menurut Kiranawati (2007) pembelajaran kooperatif model TGT (Teams Games Tournament) adalah salah satu tipe atau model pembelajaran kooperatif yang mudah diterapkan, melibatkan aktivitas seluruh siswa tanpa harus ada perbedaan status, melibatkan peran siswa sebagai tutor sebaya dan mengandung unsur permainan dan reinforcement. Aktivitas belajar dengan permainan yang dirancang dalam pembelajaran kooperatif model TGT memungkinkan siswa dapat belajar lebih rileks disamping menumbuhkan tanggung jawab, kerjasama, persaingan sehat dan keterlibatan belajar

Adapun tujuan pembelajaran yang bisa diambil dalam penelitian ini adalah untuk memperbaiki dan meningkatkan kualitas proses pembelajaran di kelas, untuk mengetahui tingkat keaktifan belajar siswa dan meningkatkan hasil belajar siswa pada mata pelajaran geografi dengan model pembelajaran kooperatif tipe TGT (Teams Games Tournament) pada mata pelajaran Geografi di Kelas X IIS 3 SMA Negeri 1 Telagasari.

\section{METODE PENELITIAN}

Penelitian ini dilaksanakan di Kelas X.IIS 3 SMA Negeri 1 Telagasari yang berlokasi di Jalan Raya Telagasari, pada semester genap tahun pelajaran 2012/2013. Subjek penelitian ini adalah siswa-siswi Kelas X IIS 3 di SMA Negeri 1 Telagasari pada semester genap tahun pelajaran 2012/2013. Jumlah siswa di Kelas X IIS 3 adalah 41 orang, antara lain 26 orang siswa laki-laki dan 15 orang siswai perempuan. Objek dalam penelitian ini adalah aktivitas belajar siswa dan hasil belajar siswa pada materi Pengetahuan Dasar Geografi dengan menggunakan model pembelajaran kooperatif tipe Teams Games Tournament ( TGT ). Penelitian ini merupakan penelitian tindakan kelas (PTK), dalam pelaksanaannya memakai siklus . Setiap siklus terdiri dari terdiri dari 4 tahapan yaitu : (1) Tahap Perencanaan Tindakan, (2) Tahap Pelaksanaan Tindakan, (3) Tahap Observasi Tindakan, dan (4) Tahap Refleksi. Pencanaan penelitian ini yang direncanakan selama 2 siklus. Pengumpulan data dalam penelitian ini 
menggunakan metode tes dan metode observasi. Alat untuk mengumpulkan data dalam penelitian ini adalah alat evaluasi yang berisikan soal-soal yang relevan dengan materi, dan dengan lembar observasi yang beisi instrument penilaian aktivitas belajar siswa. Peneliti dalam menganalisis data menggunakan metode analisis deskriptif kuantitatif , sebagai acuan penilaian peneliti menggunakan tabel acuan penilaian, sebagai berikut

Tabel 1. Acuan Penilaian Hasil Belajar dan Tingkat Keaktifan Siswa

\begin{tabular}{|l|l|l|}
\hline Persentase & $\begin{array}{l}\text { Kriteria Hasil } \\
\text { Belajar Siswa }\end{array}$ & $\begin{array}{l}\text { Kriteria Keaktifan } \\
\text { Belajar Siswa }\end{array}$ \\
\hline $90-100$ & Sangat Tinggi & Sangat Aktif \\
\hline $80-89$ & Tinggi & Aktif \\
\hline $65-79$ & Sedang & Cukup Aktif \\
\hline $55-64$ & Rendah & Kurang Aktif \\
\hline $0-54$ & Sangat Rendah & Sangat Kurang Aktif \\
\hline
\end{tabular}

\section{HASIL DAN PEMBAHASAN}

\section{Hasil Penelitian Tindakan}

Dari hasil observasi mengenai aktivitas belajar siswa maka didapatkan bahwa aktivitas belajar siswa kelas X IIS 3 SMA Negeri 1 Telagasari pada siklus I adalah 70,10\% dan aktivitas belajar siswa kelas X IIS.3 SMA Negeri 1 Telagasari pada siklus II adalah 81,67\%. Dari data tersebut menunjukan bahwa dengan menggunakan model pembelajaran kooperatif Teams Games Touenament, aktivitas belajar siswa meningkat sebesar 11,57\%

Rekapitulasi presentase aktivitas belajar siswa kelas X IIS 3 SMA Negeri 1 Telagasari pada siklus I dan Siklus II terlihat pada tabel 2 dan grafik dibawah ini.

Tabel.2 Prosentase Perolehan Hasil Aktivitas Belajar Siswa

\begin{tabular}{|c|c|c|c|l|}
\hline Objek & Fase & Presentase & PAP (\%) & \multicolumn{1}{|l|}{ Kriteria } \\
\hline $\begin{array}{c}\text { Aktivitas } \\
\text { Belajar Siswa }\end{array}$ & $\begin{array}{c}\text { Siklus } \\
\text { I }\end{array}$ & $70,10 \%$ & $65-79 \%$ & $\begin{array}{l}\text { Cukup } \\
\text { Aktif }\end{array}$ \\
\hline $\begin{array}{c}\text { Aktivitas } \\
\text { Belajar Siswa }\end{array}$ & $\begin{array}{c}\text { Siklus } \\
\text { II }\end{array}$ & $81,67 \%$ & $80-89 \%$ & Aktif \\
\hline
\end{tabular}

\section{Grafik Perolehan Aktivitas Belajar Siswa}

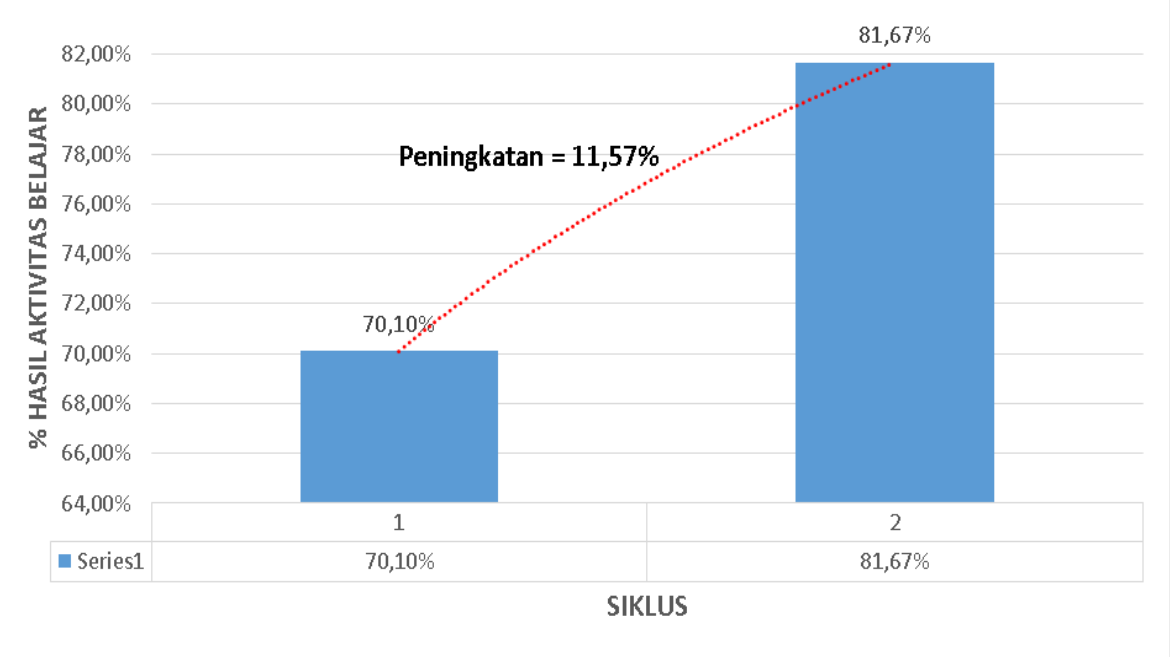




\section{Grafik 2 . Prosentase Perolehan Aktivitas Belajar Siswa}

Dari hasil penerapan model pembelajaran kooperatif tipe Times Games Tournament pada mata pelajaran geografi dengan materi pengetahuan dasar geografi, terbukti bahwa terjadi peningkatan aktivitas belajar pada siswa di SMAN 1 Telagasarii. Peningkatan aktifitas belajar yang baik salah satunya ditentukan oleh strategi belajar, pernyataan ini didukung oleh pendapat Komalasari, (2010) menyatakan aktivitas belajar dengan permainan yang dirancang dengan pembelajaran kooperatif Teams Games Tournament memungkinkan siswa dapat belajar lebih santai di samping menumbuhkan tanggung jawab, kerja sama, persaingan sehat, dan keterlibatan belajar Penggunaan model pembelajaran kooperatif tipe Teams Games Tournament memberikan siswa kebebasan untuk berinteraksi dan menggunakan pendapatnya, rasa percaya diri siswa menjadi semakin tinggi, motivasi belajar siswa semakin bertambah, meningkatnya toleransi antara siswa dengan siswa, guru dengan siswa

Selain aktivitas belajar, penerapan model pembelajaran Teams Games Tournament juga membawa pengaruh terhadap capaian hasil belajar siswa.. Capaian hasil belajar siswa yang diperoleh pada mata pelajaran geografi khususnya materi pengetahuan dasar geografi, pada kelas X IIS 3 SMA Negeri 1 Telagasari, mendapatkan hasil persentase rata-rata hasil belajar pada siklus I mencapai 73,20\% berada pada kriteria "Sedang" dan pada siklus II 80,00\% berada pada kriteria "Tinggi"sehingga mengalami peningkatan sebesar 6,71\%.

Rekapitulasi presentase perolehan hasil belajar siswa kelas X IIS 3 SMA Negeri 1 Telagasari pada siklus I dan Siklus II terlihat pada tabel 2 dan grafik dibawah ini

Tabel 3. Prosentase Perolehan Hasil Belajar Siswa

\begin{tabular}{|l|c|c|c|c|}
\hline Objek & Fase & Presentase & PAP (\%) & Kriteria \\
\hline Hasil Belajar Siswa & $\begin{array}{c}\text { Siklus } \\
\text { I }\end{array}$ & $73,20 \%$ & $65-79 \%$ & Sedang \\
\hline Hasil Belajar Siswa & $\begin{array}{c}\text { Siklus } \\
\text { II }\end{array}$ & $80,00 \%$ & $80-89 \%$ & Tinggi \\
\hline
\end{tabular}

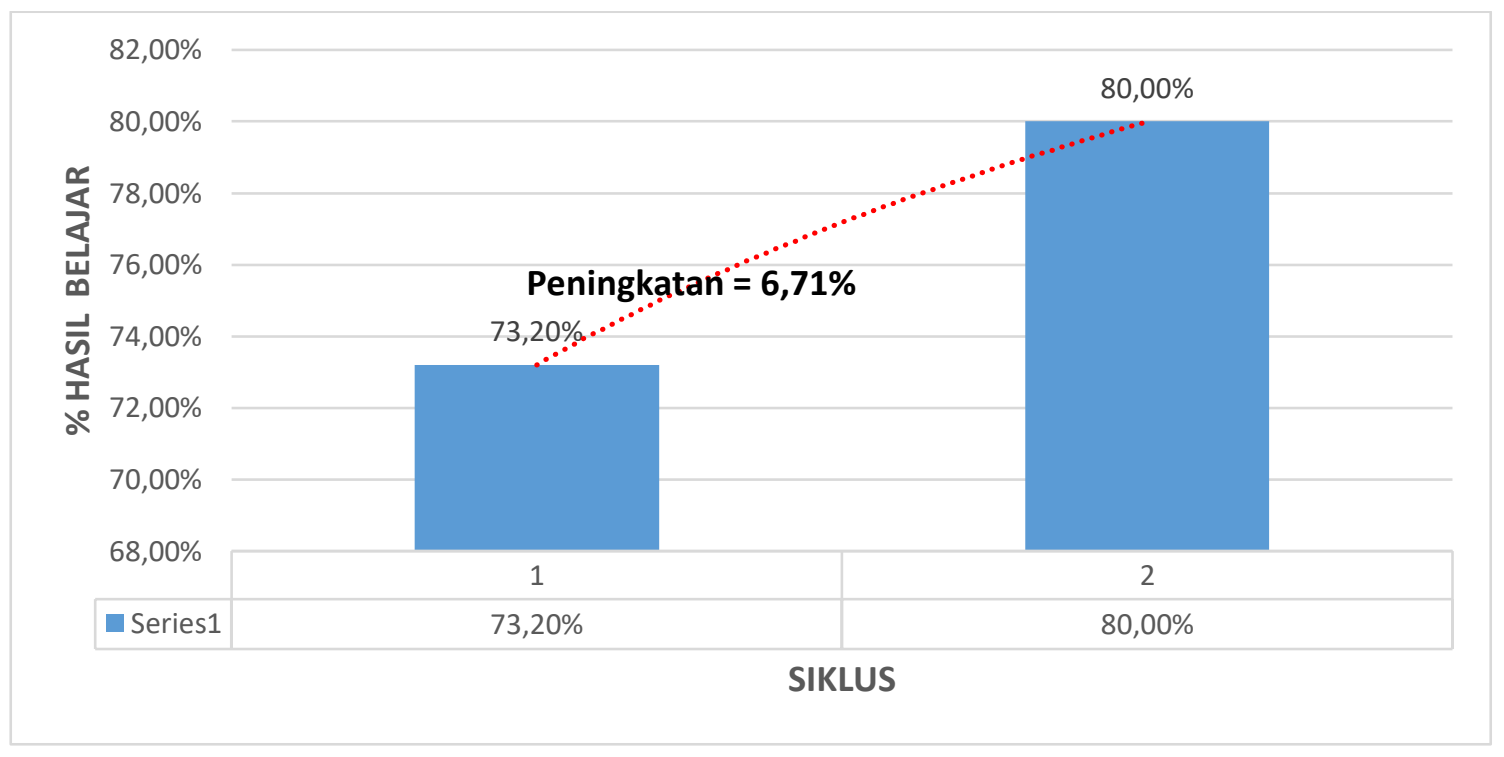

Gambar 2. Grafik Perolehan Hasil Belajar Siswa

Dari hasil penelitian telah terjadi peningkatan hasil belajar, baik pada Siklus I dan siklus II., keberhasilan belajar siswa tidak dapat terlepas dari strategi belajar- mengajar yang dilakukan, salah satunya dengan.penerapan model pembelajaran kooperatif tipe TGT (Teams 
Games Tournament). dengan terbukti bahwa aktivitas dan hasil belajar siswa Kelas X IIS 3 SMA Negeri 1 Telagasari pada mata pelajaran geografi tahun pelajaran 2012/2013 berhasil, sehingga hasil belajar siswa mengalami peningkatan yang lebih baik sesuai dengan tujuan pembelajaran.

Jadi dengan penerapan model pembelajaran kooperatif Teams Gemes Tournament (TGT) akan memperoleh hasil belajar yang tinggi, sesuai yang dinyatakan oleh teori Sudjana (2004) bahwa hasil belajar yang rendah merupakan cerminan dari hambatan yang muncul dalam kegiatan proses pembelajaran, hambatan dalam kegiatan proses pembelajaran dapat terjadi pada berbagai aspek Salah satu model pembelajaran yang mampu membantu meningkatkan aktivitas dan hasil belajar siswa dan sekaligus membantu siswa mengatasi kesulitan dalam memahami konsep, mampu mengajak siswa berperan aktif dan mampu mengarahkan siswa untuk bekerja sama dalam kelompok adalah model pembelajaran kooperatif. Dalam pembelajaran kooperatif ini guru berperan sebagai fasilitator yang berfungsi sebagai jembatan penghubung ke arah pemahaman yang lebih tinggi dan menurut Sukidin (2002) yang menyatakan pembelajaran kooperatif adalah "pembelajaran yang memandang keberhasilan individu diorientasikan dalam keberhasilan kelompok. Dalam hal ini maka siswa berusaha keras membantu dan mendorong pada teman-teman untuk bersama-sama berhasil dalam belajar"

\section{KESIMPULAN}

Berdasarkan analisis data deskriptif kuantitatif, yang diperoleh dari hasil observasi dan evaluasi dengan dua kali siklus dapat dipeoleh hasil bahwa dengan penerapan model pembelajaran Teams Gemes Tournament (TGT), yaitu pada siklus I sudah nampak ada peningkatan dari aktivitas dan hasil belajar, walaupun dengan perolehan dari aktivitas belajar pada tingkat cukup aktif dan hasil belajar tingkat sedang, namun setelah dilakukan siklus ke II semakin terlihat perolehan yang sangat signifikan, memperoleh aktivitas belajar pada tingkat aktif dan perolehan hasil belajar pada tingkat tinggi.

Jadi berdasarkan hasil penelitian dan tindakan yang peneliti lakukan dapat disimpulkan, bahwa dengan penerapan model pembelajaran Teams Gemes Tournament dapat meningkatkan aktivitas dan hasil belajar siswa mata pelajaran geografi di SMA Negeri 1 Telagasari.

\section{DAFTAR PUSTAKA}

Isbani. 1997. Pembelajaran Kooperatif dalam Pembelajaran. Tersedia pada : http://pembelajarankooperatifartikel.blogspot/1997/isbani-pembelajaran . Diakses pada 20 Januari 2013 jam 11.30

Jihan dan Haris.2008: Psykolog Pendidikan. Yogyakarta : Erlangga 1994.

Komalasari, Kokom.2010. Pembelajaran Konstektual : Konsep dan Aplikasi. Bandung : Refika Aditama

Slavin, R. 1990. Cooperative Learning : Theory, Research ang Practice. Englewood Cliff, NJ: Prentice Hall.

Sudjana, Nana. 2004. Penilaian Hasiul Proses Belajar Mengajar, Rosda

Sukidin, dkk. 2002. Metode Penelitian TindakanKelas, Insan Cendikia

Sumatmaatmadja, Nurdin. 2005. Metodelogi Pengajaran Geografi. Jakarta : Bumi Aksara.

Tampubolon, Saur. 2013. Penelitian Tidakan Kelas: Sebagai Pengembangan Profesi Guru dan Keilmuan, Erlangga

Taniredja ,dkk. 2011. Model-Model Pembelajaran Inovatif-Progresif. Jakarata:Kencana 